\title{
The Ethnolinguistic Identity of the Hamap People in Change ${ }^{1}$
}

\author{
Ninuk Kleden-Probonegoro \\ Research Centre for Society and Culture \\ Indonesian Institute of Sciences
}

\section{Introduction}

This research was conducted after the law (No. 22/1999) on regional government had been in force for more than five years, where one of the central issues in the 'regional autonomy era' is identity. Alor, a regency in East Nusa Tenggara Province with its 16000 islands, is a region that is conscious of its identity; it is distinct from Timor, as well as from other regions in West Nusa Tenggara and from other areas in Indonesia. Nevertheless the question remains whether Alor is able to sustain its cultural identity in an area that is inhabited by a range of ethnic groups speaking 18 different local languages (SIL International 2001).

One of the ethnic groups in Alor is the Hamap people. The Hamap live in southwest Alor, in Moru village to be specific, and they are surrounded by other ethnic groups; the Abui, the Klon, the Mor, the Adang, the Kabola and the Pura people. The Kui people are considered to be of foreign origin. This belief is legitimised by a mythological kinship between the Hamap and other ethnic groups. There are also other groups: migrants from Flores, Timor and Java.

1 This summary is based on the research report by PMB-LIPI. The research was conducted by Ninuk Kleden-Probonegoro, Katubi, Fany Henry Tondo and Imelda. 
As well as in Moru village, there are Hamap people in Moramam and Wolwal villages. ${ }^{2}$ Compared with the population as a whole, the Hamap people are a minority. Economically, they have a subsistence economy and they are subordinate to other ethnic groups. The Hamap language can also be categorised as a minority language because the number of its speakers is small, around 100000 people (SIL International 1986) although parents and children whose parents are of Hamap descent still use the language. Grimes (2001) describes this condition as stable but threatened but Crystal (2000: 20) considers it a language at stake because although it is spoken by a fairly large number of people it is in good condition in only a few communities. If the social and cultural situation is not conducive to a language's maintenance it will disappear. In Indonesia, languages at stake are those of minorities such as the Hamaps.

Although it is one of the surviving languages among the languages in southwest Alor, the Hamap language is not very resilient and has weak ethnolinguistic vitality. It is no wonder that the Hamaps, a minority group, have developed into a bilingual community. The Alor-Malay language is the lingua franca along with the other ethnic languages, such as the languages of the Kuis and the Abuis. Such a linguistic situation has caused diglossia, that is, a society that uses two or more languages in different social functions and social contexts (Saville-Troike 1986: 56). It is this pluralistic and diglottic culture that is the background of this research.

If a language can be treated as an ethnic marker, then how far can the ethnolinguistic identity prevail if the communicative function of the language changes in proportion to other changes in the society?

This research assumes that there is an inherent relationship between a language and an identity because a language can be concomitant with the members of an ethnic group. A language has expressions, norms, values that can be important attributes of a set of language speakers.

2 We did not give attention to Wolwal village because it is separate, is more remote and its people are Muslim. Hamap people in Moru and Moramam practice Protestantism (which is relevant as far as the influence from the church and the Dutch is concerned). 
The connection between identity and language features the concept of ethnolinguistic identity, which, in this research, is based on the cognitive definition of ethnic group membership where individuals identify themselves as being part of an ethnic group.

This research starts from three hypotheses: (i) the weak ethnolinguistic vitality has an effect on the shift in the communicative function of a language. It is assumed that the linguistic change is influenced by various factors external to the language itself, but (ii) referring to Foley (1997: 381), the linguistic change may take place because of internal factors and (iii) Hamap mythology relates the journey of their ancestors who were the progenitors of ethnic groups. If, mythologically, the Hamaps consider themselves to have ancestors in common with the Abuis, the Adangs, the Kabolas, the Mors and the Puras, then they must have a linguistic kinship.

\section{Ethnolinguistic Vitality}

There are three indicators of ethnolinguistic vitality: geographic condition, demography and socio-cultural conditions.

\section{Geographic and Demographic Condition}

The combined population of the villages of Moru, Moramam and Wolwal in 2006 was 4071 people of which 1000 were Hamaps. Therefore, from a demographic point of view, that is, the number of speakers of a language, the Hamaps are considered a minority.

The Hamap language community is in a social context that requires them to engage with other ethnic groups, especially the Kuis, the Klons, the Abuis, because these three ethnic groups live in the same village. In Moru, however, the Hamaps live in three rukun tetangga (RT), a term best translated as 'neighbourhood': RT 001, RT 004 and RT 006. Obviously, being a minority, the Hamaps are not an isolated community, although its linguistic vitality is weak. In principle, the more isolated are the users of a language, and the less contact those users have with other ethnic groups, the stronger is its linguistic vitality. 


\section{Social and Cultural Conditions}

Judging from these conditions, this research presupposes that linguistic change is influenced by factors external to the linguistic aspects themselves. One of the important factors is the immediate economy; in big cities people tend to learn and use English because it has economic benefits. Economic analysis indicates that the subsistence economy of the Hamaps has not developed into a market economy (Scott 1994, Polanyi 1978). There are three main causes.

First, slash-and-burn farming is done through the principle of reciprocity, kumpul tangan [join hands], and baku kunci [interlock], perpuluhan (a tithe to be presented to God) and balui, an organisation that distributes the main staple foods to widows and orphans. This type of social insurance is peculiar to subsistence societies because the burdens of the costs of production and common livelihood are borne collectively. They also choose not to take too much profit; instead, they feel happy with a small profit or no profit at all, as long as their community survives harmoniously. Their custom that prevents economic progress is that they are prohibited from selling rice and maize, the two main agricultural crops. ${ }^{3}$

Second, they sell only produce that comes from their own backyard; green and red peppers, pumpkins, other vegetables, papaya and bananas. They sell their produce in traditional markets once a week at relatively low prices.

Third, canary trees (Canarium commune), and other local plants that might be exploited commercially, are seen simply as local resources. Commercial cultivation of canary trees for their nuts has not been considered. The canary trees have been there in the mamar (common land on the hillsides) since the first generation of the Hamaps.

Subsistence economies based on slash-and-burn farming are not directly

3 Southwest Alor subdistrict produces 13.67 per cent maize and 11.64 per cent rice of the total production of Alor regency. In contrast, fishery covers only 6.17 per cent. 
connected to linguistic change but are connected with the floating unemployed (Dieter-Evers 1988), that is, the youths who do not want to be farmers but are unemployable outside the agricultural world. They gradually abandon their language (see description below).

\section{Language and its Changes}

Beside demographic, social and cultural factors that form the background of changes, linguistic change is also triggered by code shiftig, language choice, the ideology of language and naming and addressing system.

\section{Code Shifting and Language Choice}

For Bernstein, code not refer to variant on system level, but to intergroup or intersubgroup comparision. Consequently, there is a conceptual difference between we-code and they-code.

Code analysis shows that for the Hamaps, the Hamap language has the we-code while the languages of other ethnic groups have the theycode. In the meantime, Alor-Malay and Bahasa Indonesia have the wecode with different coverage. Alor-Malay, spoken by various ethnic groups in Alor, has an inclusive we-code, while Bahasa Indonesia has an exclusive we-code because the language is mastered by a small set of people only, in particular by those Alorese with tertiary education and who work outside the Alor region.

However, on various occasions, the Hamaps can shift their code. This indicates the membership flexibility in a language community but not the flexibility of ethnolinguistic identity. As a multilingual group, the Hamaps have never considered Klon language as their ethnic language, although they are fluent enough in the language. For Seba and Wooton (1998: 276), it is the linguistic behaviour that determines the shift in the identity of the speaker, because through this linguistic behaviour one 'proclaims' his or her identity; through vocabulary selection, articulation, and the language that has been chosen to use.

Some aspects of language choice among multilingual societies can 
be explained in practical, political and economic terms. Nevertheless, the language role in determining cultural identity is closely related to extra-linguistic aspects, one of which is the vertical relations between speakers.

Participants is one of the speech event components (Hymes 1972). Language between perticipants is made on the one hand by the difference in vertical dimensions: age, social status, and economic position as well as economic stratification, and on the other hand by horizontal dimensions, that is, by the degree of solidarity between the participants.

Our interviews revealed that many young people use a mixed language, that is mixture of the Hamap language, Alor-Malay and Bahasa Indonesia, or a Hamap sentence with some Indonesian words. For example, kasibota sepatu. Young people no longer understand the word sepatu or shoes in the Hamap language.

Another example, na mau hae. In this sentence the Indonesian word mau [want] is inserted in between two Hamap words. Na means 'I' and hae means 'like this' in Hamap.

This condition happens because socialising necessitates the use of other languages. In this case, the attractiveness of Alor-Malay and Bahasa Indonesia is apparent. From identity affirmation viewpoint, ethnic languages play the same role. However, as far as means of communication are concerned, the equality between languages stops. Alor-Malay and Bahasa Indonesia suddenly metamorphose into wecode, and sometimes they-code.

Language choice has indicated a cultural identity change. This can be deduced by differences in understanding between younger and older generations. Old people sometimes do not understand anymore what is being said by young people because they mix the Hamap language with Alor-Malay and Bahasa Indonesia. The young people, on the other hand, feel that the old people are too narrow-minded. 


\section{Language and Naming Ideology}

\section{Language Ideology}

Analysis of linguistic ideology includes language ideology that consists of systems of ideas, language behaviour and the ideology of personal naming. The Hamaps, young and old generations, still appreciate their language. This appreciation for an ethnic language does not cause them not use other languages, that is, Bahasa Indonesia and now English, which is being taught at school.

A great many of the Hamap younger generation will admit that they have a poor command of the Hamap language. Nonetheless, they expect that the Hamap language can be preserved. When this research was underway, the village people still used the language in customary ceremonials and in village formal meetings. Outside their daily language use, the Hamaps recognise the existence of high language and deep language. If the high language is not understood by the laity (common people) because it is used only in rituals, then this is not the case with deep language, which is expressed in metaphors. For example, 'karba gatuk ben giap kabi gatuk ben ate tabaga nanga', has the meaning that buffalo hooves are different from goat hooves. This deep language is usually used by parents of common people whose son has been seen socialising with a girl from suku raja or the nobility as a warning that they would not be able to pay the belis or bride-price. The Hamap language is little used by Hamap young people in conversation; they prefer using a mixed language.

\section{The Ideology of Naming}

Name is a method of classifying oneself and positioning oneself in society, so that in the ideology of naming, a name does not any more belong to an individual, but has social, collective and conventional aspects. The Hamaps recognise two classifications of names: baptismal name and halaik name or name from the community, which is considered original. As soon as a baby is born and its sex is made known, it must get a halaik name. The name of a grandfather is used for a male baby, 
and the name of a grandmother is used for the female baby. The use of Christian names among the Hamaps began with the introduction of Christianity in 1920. Giving baptismal names by the church in former times was done alphabetically. If the halaik name of the baby to be baptised begins with the letter A, for example Airtang, then its baptismal name would begin with A too, for example, Ayub.

A baptismal name is given three days after a baby is born. It has become a custom that the halaik name is replaced by the baptismal name. Actually the Hamaps can put their halaik name in front of their baptismal name, but this is rarely done and this has led to the disappearance of halaik names, leaving only the baptismal name for official usages, for example, school enrolment.

So the halaik name, once used to preserve the memory of ancestors, is neglected by the church because in the church register only the baptismal name and the family names are recorded. Even now there is a trend among young families to name their children according to popular taste, that is, by using the names of celebrities, world soccer champions, Miss Universe or movie stars for their newborns.

\section{Addressing System}

In the Hamap language, there are three forms to use when addressing someone: the name used to address someone, a form of addressing that has to do with kinship and a new form of addressing. The Hamaps do not want to be addressed by their halaik name but by their baptismal name. Bilateral structure with ambilineal principles among the Hamaps can be verified by the fact there is no difference in terminologies for the paternal group and the maternal group. All grandfathers and grandmothers from the first, second and third levels are called $b a b$. References to males and females are distinguished by the suffix $o b$ for females and lotte for males.

Now there are new addressing forms because of inter-language contacts directly with Alor-Malay and Bahasa Indonesia, and indirectly with foreign languages, especially with Dutch that arrived together with the Christianity. Addressing with a male family name, or om for 'uncle', 
which is a loan word from Dutch oom and tanta for 'aunt' (or tante in Dutch) is clearly of Dutch origin and introduced with Christianity. This shows that the constructed identity refers to the world outside of Hamap culture, meaning that a cultural change has taken place. The language with Hamap culture-code has shifted to another language external to Hamap culture.

\section{Mythology and Linguistic Kinship}

Hamap mythology consists of six purba (episodes) that tells the story of the migration of the Hamap people from Mount Kukusan in Southwest Alor to Central Alor and then to Pura, an island east of Alor. Purba I tells the story of Bab Hiftarsah, the ancestor of the Hamap people and who had four children. The first and the second children generated the $\operatorname{suku}(\mathrm{s})^{4}$ with their rights and obligations. ${ }^{5}$ Purba II, III and IV relate the chronicles of the $b a b$ who travelled from place to place because of assaults from snakes, bees, fish and floods. They founded their compound whose name and place are still known up to now. The problem is to what extent is there a correlation between the ethnic etymologies and the languages? To answer this question, the researcher employed the method of historiccomparative linguistics with lexico-statistical techniques.

In fact, there has been research on linguistic kinship, but without connection to mythology. The Adang language, according to Gordon (2005), in 2000 was spoken by 31814 speakers and had an Aimoli dialect, which is different from Kabola language. Johnston (Gordon

4 The concept of suku among the Alorese is understood as lineage in anthropology.

5 Suku Raja (Avin Lelang) is the grandchild of Bab Hiftarsah from his eldest son Hamap Bel who has a role of solving the problems unsolvable by his younger brothers. As the eldest son, this suku has the right to lead the Hamap people. The other descendant is Suku Tafa who functions as an arbiter to resolve conflicts. Suku Di executes the decision already made by his older brother. Suku Tofa has a job of reporting to the king all suspectible things, and newcomers and their offspring who are allowed by Hamap Bel to live in O'ta compounds, outside the Hamap compounds, are known as Suku Menbang who is assigned to guard the whole kampong. The second child of Bab Hiftarsah has three sons: suku Hukung who presides over a trial, suku Marang who takes care of the altar, the place where religious rituals are carried out, and the third child is the one without name, and has no specified job. 
2005) said that the Kabola people, who numbered 3900, had a language distinguishable from the Adang language. Wurm and Hatori (Gordon 2005) added that the Kabola language had four dialects whose names were similar to the names of kampongs in Kabola. Kratochvil (2007) said the Abui language was spoken by 16000 people who, according to Ethnologue (Gordon 2005), had Atimelang, Kabola and Alakaman dialects. Ethnologue did not mention the Mor and Pura languages, because from this research it appeared that the Mor people remained just one family and the Pura language, in Ethnologue, was considered a dialect of the Blager language. Katubi in his report (2004) found that among the Pura language speakers there was one family who used Habolot. It is worth noting that the finding was based on the data in Monografi Kosakata Dasar Swadesh di Kabupaten Alor [Monograph on Swadesh Basic Vocabulary in Alor Regency] of the year 2000.

The status of linguistic kinship was examined using lexico-statistical methods. Through this technique, languages can be compared and categorised in terms of dialect, family, cluster, microphylum, mesophylum and macrophylum based on the number of basic vocabularies taken from Swadesh (Keraf 1984: 123-124). The table below shows the percentage of kinship between the languages spoken by $b a b$ Hiftarsah's generations.

Table 1

Percentage of linguistic kinship between

$B a b$ Hiftarsah's generations

\begin{tabular}{|l|l|l|l|l|l|l|}
\hline & 1 & 2 & 3 & 4 & 5 & 6 \\
\hline 1 & & & & & & \\
\hline 2 & 87 & & & & & \\
\hline 3 & 45 & 46 & & & & \\
\hline 4 & 76 & 78 & 45 & & & \\
\hline 5 & 87 & 81 & 44 & 71 & & \\
\hline 6 & 61 & 59 & 41 & 59 & 60 & \\
\hline
\end{tabular}

Source: Field Data 2007

Ethnic group figures

(1) Hamap, (2) Adang, (3) Abui, (4) Kabola, (5) Mor and (6) Pura 
The above table shows three things: (i) the Hamap language is close to the Adang and Mor languages. Both have 87 per cent similarities in basic words; (ii) the Hamap language is fairly close to the Kabola language (76 per cent similarities in basic words) and the Pura language (61per cent); and (iii) the Hamap language is distant from the Abui language (35 per cent similarities in basic words).

The figure depicts the relationship between the isolects of the languages only and does not necessarily indicate the kinship status, which can be known only after the languages are classified into diction variations (Keraf 1984: 135). ${ }^{6}$

Figure 1

Linguistic Kinship between Bap Hiftarsah's generations

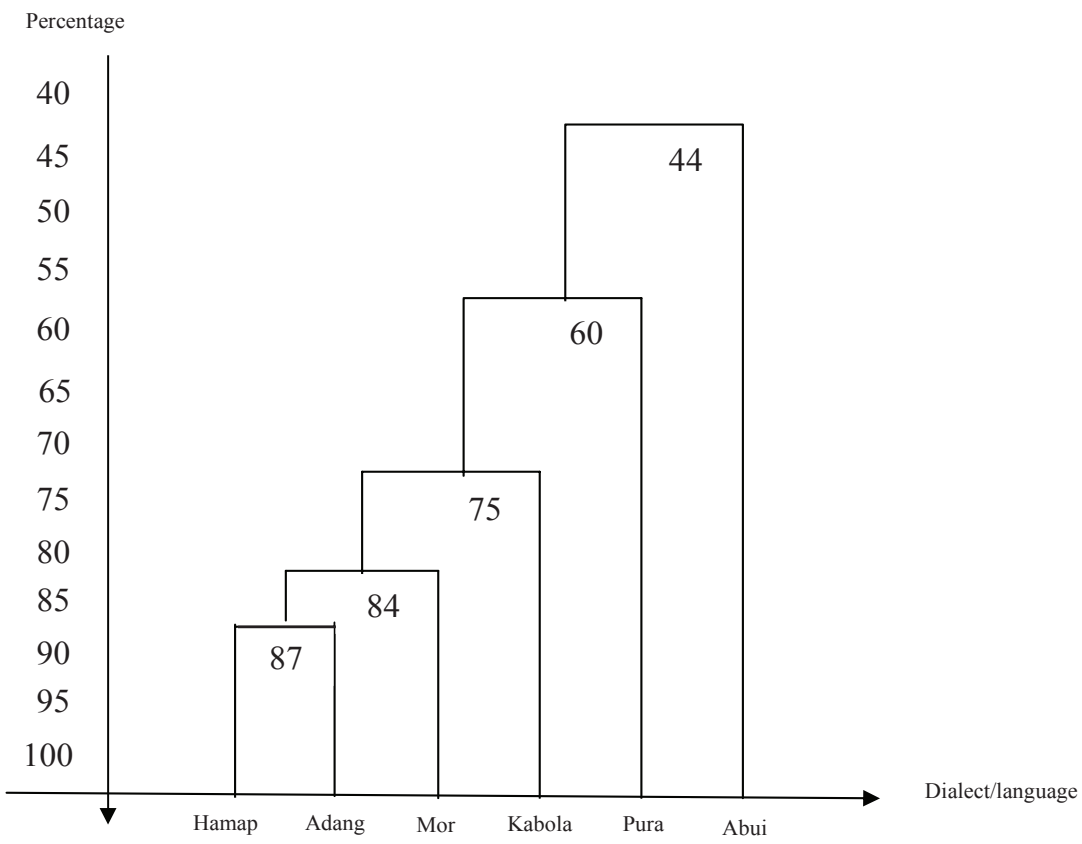

6 The dialect status is given to an isolect that has 81 to 100 per cent similarities with another language; 36 to 81 per cent indicates that isolects exist in different languages but still in the same language family and 12 to 36 per cent shows that the isolects are in the same language cluster. Other percentages, 4 per cent or below indicate the statuses of microphylum, mesophylum and macrophylum (1 per cent). 
Based on the average value and calibration using language classification there are two findings. The first is that Hamap, Adang, Kabola, Mor and Pura languages are in one language family. The second is that the language family has different statuses of familial relationship. The Hamap, Adang and Mor languages have the status of dialect, because the Hamap language has an 87 per cent similarity in basic vocabularies with the Adang language and 84 per cent with the Mor language. As regards the Kabola, Pura and Abui languages, their status is of distinct languages because they have only 76 per cent, 61 per cent and 45 per cent similarities respectively in basic vocabularies with the Hamap language. Therefore, in that language family there are three dialects and four languages, whose ethnic groups are mythologically considered siblings.

\section{Conclusion}

In discussing the fluid ethnolinguistic identity of the Hamap people, we first of all tried to define the ethnolinguistic boundaries by examining their mythology. The Hamap mythology tells about the migration of their first ancestor and his descendants who, in the course of time, developed into the Adang, Kabola, Mor, Pura and Abui ethnic groups. If, mythologically, the Hamap people have an affinity with the other five ethnic groups, then lexico-statistical tests would show that the ethnic groups mentioned in the mythology are of the same language family but with different statuses. The language group with the most distant affinity to the Hamap language is the Abui language.

The Abui mythology has it that their ancestors were two brothers who came from Papua. They quarrelled, one of them left, and it was his descendants who are the Abui people. If this is so, then why, according to Hamap mythology, did Tangmo and Pandamo from Molmoti go to Gunung Besar and their offspring become the Abui people? There are two things that can be delineated from this narration: first, the Abui mythology supports the historic comparative linguistic analysis that classifies this language as a distinct language because it has only 45 per cent basic similarities in vocabulary with the Hamap language; and, second, this seems to be the way the Hamap people try to legitimise 
themselves, an effort that also functions as a resistance mechanism to the influence of other multilingual ethnic groups.

Thus, mythological imagination has brought the spoken linguistic kinship into reality. The shifting Hamap ethnolinguistic identity can be seen from the shifts in codes, and changes in the ideology of language in naming as well as in addressing. If the mythology can be understood as a core identity for the other ethnic groups that are have a common linguistic kinship with several dialects, then the addressing system refers to language groups external to the Hamap language, namely Alor-Malay, Indonesian and Dutch. In other words, the Hamap ethnolinguistic identity is constructed as divergent by mythology and as convergent by the addressing system.

\section{References}

\section{Books and Journals}

Bernstein, JM. 2001. 'Grand Narratives', in Paul Ricoeur (ed.). Narratives and Interpretation. London: Routledge, pp. 102-103.

Crystal, David. 1987. The Cambridge Encyclopedia of Language. Cambridge: Cambridge University Press.

Dieter-Evers, Hans et al. 1988. 'Reproduksi Subsistensi, Suatu Kerangka Analisis', in Dieter-Evers (ed.). Teori Masyarakat: Proses Peradaban Dalam Sistem Dunia Modern. Jakarta: Yayasan Obor Indonesia, pp. 162-180.

Fooley, William A. 1987. Anthropological Linguistics: An Introduction. Oxford: Blackwell

Grimes, Barbara F. 2001. 'Kecenderungan Bahasa Untuk Hidup atau Mati Secara Global: Sebab, Gejala dan Pemulihan untuk Bahasa-Bahasa yang Terancam Punah'. Makalah PELBBA 15. Unika Atmajaya.

Hymes, Dell. 1972. 'Models in Interaction of Language in Social Life', in Gumperz and Hymes (eds). Directions in Sociolinguistics. New York: Holt, Rinehart and Winston.

Katubi (ed.). 2004. Bahasa dan Kebudayaan Hamap: Kelompok Minoritas di Alor. Jakarta: Laporan PMB-LIPI.

Keraf, Gorys. 1984. Linguistik Bandingan Historis. Jakarta: Gramedia Pustaka Utama.

Kratochvil, Fransitek. 2007. A Grammar of Abui: a Papuan Language of Alor (Part 1). Utrecht: Landelijke Onderzoekschool Taalwetenschap (LOT). 
Polanyi. Karl. 1978. The Great Transformation. Frankfurt: Shurkamp.

Saville-Troike, Mauriel. 1986. The Ethnography of Communication: an Introduction. New York: Basil Blackwell.

Scott, James C. 1994. Moral Ekonomi Petani: Moral Ekonomi Subsistensi di Asia Tenggara (terjemahan). Jakarta: LP3ES.

SIL International, Indonesian Branch. 1986. Languages of Indonesia. Jakarta: SIL International.

Sebba, Mark \& Tony Wooton. 1998. 'We, They and Identity: Sequential versus Identity-related Explanation in Code-switching', in Peter Auer (ed.). Codeswitching in Conversation: Language, Interaction and Identity. London \& New York: Routledge.

\section{Website}

Gordon, Raymond G Jr (ed.). 2005. Ethnologue: Languages of the World. 15th edn. Dallas. Texas: SIL International. Online version: http.://www.ethnologue.com/ 